\title{
Managing and Surveying the Geological Garden at Tata (Northern Transdanubia, Hungary)
}

\author{
István Szente ${ }^{1}$ (D) $\cdot$ Bence Takács ${ }^{2}$ • Erzsébet Harman-Tóth ${ }^{3}$ - Tamás G. Weiszburg ${ }^{1}$
}

Received: 10 December 2018 / Accepted: 6 September 2019/Published online: 14 November 2019

(C) The Author(s) 2019

\begin{abstract}
The Geological Garden at Tata is an open-air geological museum where a spectacular succession of Tethyan Mesozoic sedimentary rocks, characteristic of the Alpine-Carpathian region, is finely exposed in abandoned quarries and cleaned rock surfaces. In addition to geological values, the area houses copper-age chert mines, the only ones accessible to the wider public in Hungary. Due to financial problems, however, maintenance of the site was more or less confined to mowing for more than 20 years. Renewal of the Geological Garden began in 2015 when large-scale cleaning as well as detailed surveying was carried out. Removing the soil and loose rock debris provided opportunity to study the effects of weathering and growth of vegetation. Near $60 \mathrm{~m}^{3}$ of rock debris and soil had been accumulated on approx. $5000 \mathrm{~m}^{2}$ rock surface over the decades of obligate deterioration. Lower Jurassic marl and Middle Jurassic radiolarite chert beds as well as Middle Jurassic limestones proved to be especially deeply weathered. The cleaning action raised the question whether the sub-horizontal rock surfaces can be conserved for a long time in their present state or not. Lessons drawn from the latter can serve as a basis for future maintenance activities as well as for plans aiming at developing geosites.
\end{abstract}

Keywords Open-air geological museum · Geosite maintenance · Surveying · Peri-Tethyan Mesozoic · Prehistoric mining · Hungary

\section{Introduction and Historical Background}

The territory of Hungary, although characterized by surface rocks and sediments of Neogene and Quaternary age, is relatively rich in scientifically important and/or spectacular geosites representing earlier periods of Earth history, and some of them were given statutory protection long ago. Recently, Horváth and Lóczy (2015) gave a detailed overview

This article is part of the Topical Collection on Geoheritage and Conservation: Modern Approaches and Applications Towards the 2030 Agenda, IX ProGEO Symposium, Poland, 25-28th June, 2018

István Szente

szente@ludens.elte.hu

1 ELTE Tata Geological Garden, Pázmány P. s. 1/c, Budapest 1117, Hungary

2 Department of Geodesy and Surveying, Budapest University of Technology and Engineering, Müegyetem rkp. 3, K ép., Budapest 1111, Hungary

3 Eötvös Museum of Natural History, Pázmány P. s. 1/c, Budapest 1117, Hungary about the state of geoconservation in Hungary, with special reference to the history, legal background and organization of geoheritage protection. The Act on Nature Conservation (53/ 1996), in force since 1996, provides the basis for protection of "geological formations and scientifically important geological exposures as well as of major localities of rare minerals or fossils" (https://net.jogtar.hu/jogszabaly?docid=99600053. TV). Nowadays, the Ministry of Agriculture holds responsibility for nature conservation and maintains a public database of protected geosites, available only in Hungarian. According to it, about three-fourths of the 195 important geological exposures located in areas protected by a specific law, such as national parks, landscape protection areas and nature conservation areas, are Palaeozoic and/or Mesozoic suites (http://www.termeszetvedelem.hu/index.php?pg=menu 2237). Another 88 geosites are protected by a specific law as nature monuments, about 28 of which are also outcrops of preNeogene rocks (http://www.termeszetvedelem.hu/orszagosjelentosegu-egyedi-jogszaballyal-vedett-termeszetiteruletek). The number of Palaeozoic and Mesozoic exposures located in protected natural areas of local interest is around ten. Abandoned quarries receive less attention than 
underground mines if their protection and conservation is considered, as a rule (Storemyr 2006). In Hungary, however, they are well represented among protected geosites.

Many of the most important geosites are concentrated in the Transdanubian Range, where Mesozoic and Cenozoic sequences are not metamorphosed and usually have not suffered considerable post-depositional deformations. Most of the exposures are, however, scattered and far from roads and settlements. One of the few exceptions to this rule is the town Tata, situated at the foot of the Gerecse Mountains around $70 \mathrm{~km}$ to the west of Budapest (Fig. 1). There a finely exposed succession of Mesozoic sedimentary rocks characteristic of the Alpine-Carpathian region can be studied in abandoned quarries and cleaned rock surfaces of the Kálvária Hill (Calvary Hill, if translated), a fault-bounded rocky horst of around $150 \mathrm{~m}$ altitude above sea level (Fülöp 1976; Haas 2007).

Tata and its environs are relatively poor in natural building stones. With the exception of occurrences of Pleistocene freshwater limestone, hard rocks have been found to crop out almost exclusively on the slopes of the Kálvária Hill, located west of the Lake Öreg (Old Lake, if translated). The variegated Triassic, Jurassic and Cretaceous limestones aroused the interest long ago and were extensively quarried for centuries. The Lower Jurassic red limestone, often called "marble" is far the most conspicuous of them and has been especially widely used. Robert Townson, an English traveller and nature historian who visited Tata (that time called Dotis or Totis) in 1793, characterized it as "a town built upon a rock of variegated red marble" (Townson 1797). Scientific study of the Mesozoic succession began with the pioneering work of acknowledged nineteenth century Austrian geologists. Franz Ritter von Hauer and Carl Ferdinand Peters recognized the presence of Lower Jurassic red ammonite limestone and Upper Triassic Dachstein Limestone, respectively (von Hauer 1853; Peters 1859). Lower Cretaceous (i.e. Aptian) beds lying unconformably on Upper Jurassic rocks were discovered by the distinguished Hungarian geographer and geologist Lajos Lóczy sen. (Lóczy 1906). The first detailed account on the stratigraphy of the Kálvária Hill was given by Koch (1909). Observations were made mostly in three quarries, called "Whitestone", "Redstone" and "Bluestone", operating those times (Fig. 2).

The 1950s of the twentieth century saw a renewed interest in the Mesozoic of the Kálvária Hill, resulting in the comprehensive papers of Fülöp (1954) and Szabó (1961). József Fülöp (1928-1994), an almost plenipotentiary actor in geology from the early 1950 s to the end of 1980s, i.e. the time of changing in society in Hungary, had the opportunity to make large rock surfaces clean in order to study Middle and Upper Jurassic rocks that have never been quarried being unsuitable for building. Detailed geological survey carried out by him has lead to the recognition of scientific and educational importance of the Kálvária Hill Mesozoic succession, and a part of the hill was declared to be a nature conservation area in 1958. In the course of geological study, two chert mining pits dug by the Copper Age man in Middle Jurassic radiolarite were discovered in the late 1960s (Fülöp 1973). The pits, now protected by an exhibition building, are the only prehistoric mining sites accessible to visitors in Hungary. In addition to the geological and archaeological exploration, Fülöp intendedly converted the dusty abandoned quarries into a garden
Fig. 1 Location of the Tata Geological Garden

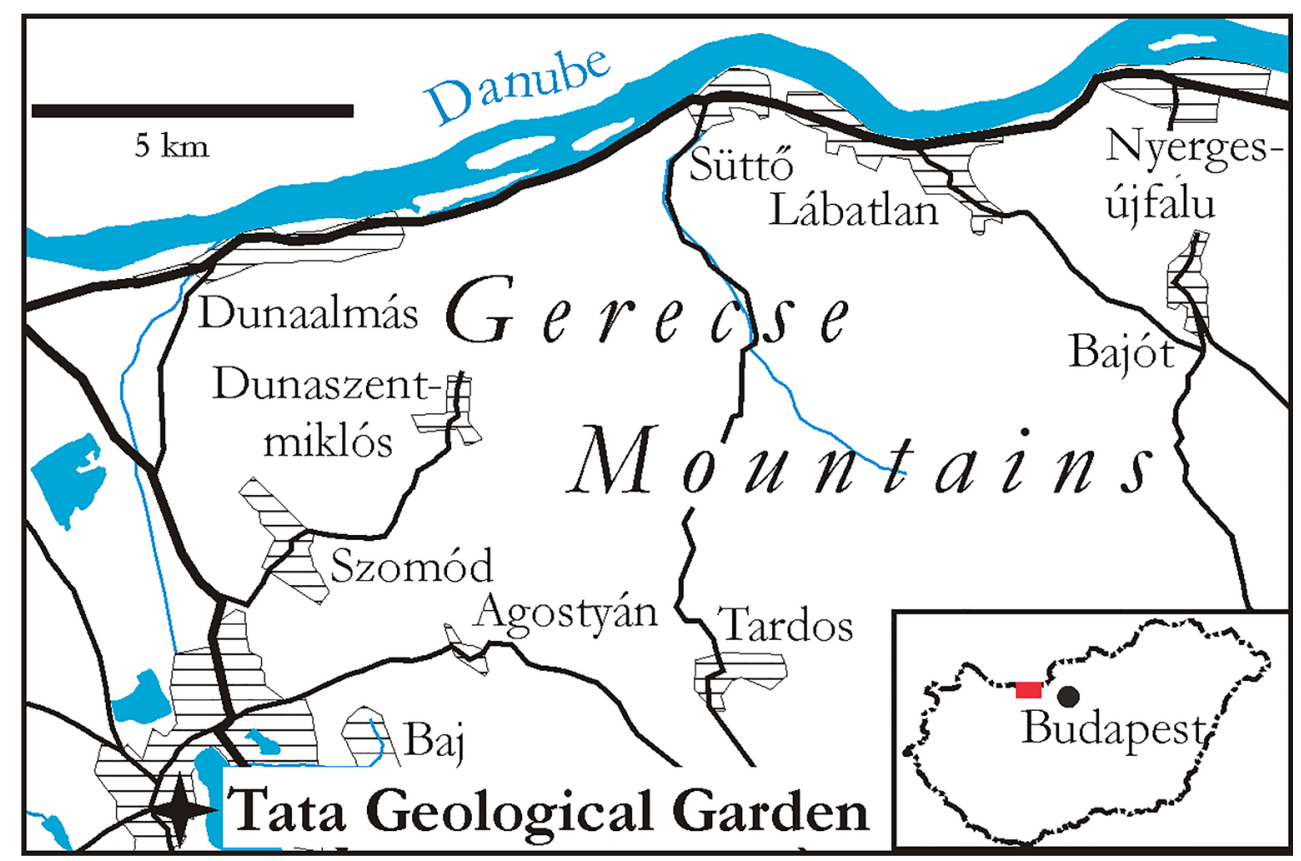


Fig. 2 Geological map of the Kálvária Hill and adjacent areas with location of the exposures mentioned in this paper. Cenozoic formations are not shown except Pleistocene freshwater limestone (after Fülöp 1976, modified)

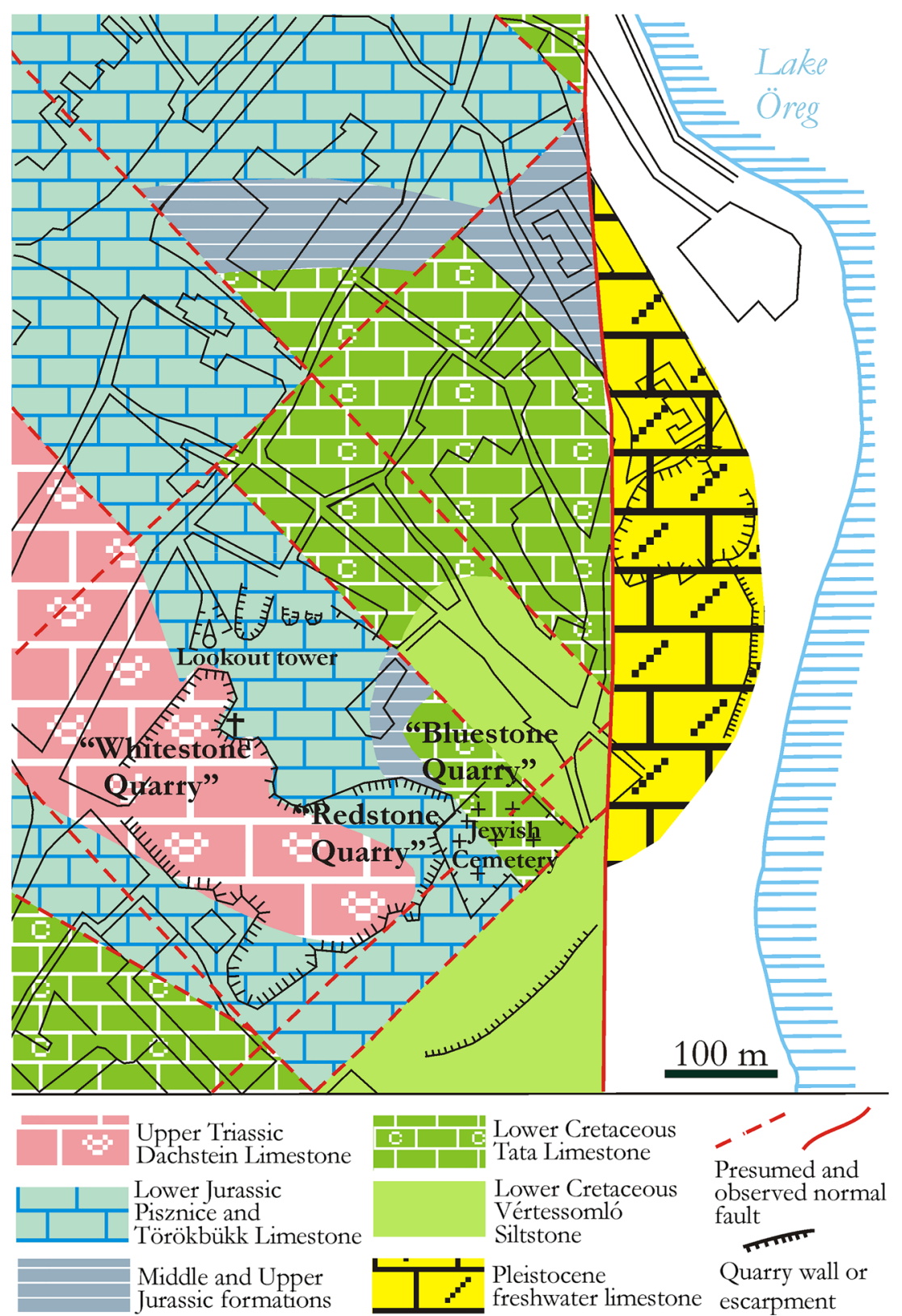

in every sense. As a result of this effort, the Geological Garden now houses a wealth of botanical values.

Quarrying came to an end completely in the late 1970s. By this time, the extent of the protected area had increased step-by-step to 3.5 ha and since 1976, it acts as an open-air geological museum, founded by the former Hungarian Geological Institute. The management of the site, now called at full-length "ELTE Tata Geological GardenNature Conservation Area and Open-Air Geological Museum", was taken over by the Eötvös University in 1994. Since then, it functions as a place for public outreach, recreation and teaching. In addition to its educational and cultural importance, the Kálvária Hill holds scientific values and is considered as a geosite sensu Brilha (2016,
2018). Its extent, visibility and accessibility (corresponding to "potential use values" in Beranová et al. 2017) make the Geological Garden one of the most valued Hungarian geosites.

Economic problems related to the democratic transformation in Hungary dramatically influenced the history of the conservation of geosites including that of the Geological Garden. Until 1992, technicians from the Geological Institute cleared away the soil and loose rock pieces as well as plants from the rock surfaces in the summer months. Around 1600 man-hours were needed once in 2 years to keep the area clean. In addition to the termination of this service, budgetcuts resulted in the reduction of the staffmembers from 5 to 2 , making maintenance rather difficult. Rocky surfaces 
became more and more vegetated and covered with loose rock pieces and soil. Reconstruction of the Geological Garden began in 2015 in form of a large-scale cleaning and surveying action. Lessons drawn from the latter, reviewed below, can serve as a basis for future maintenance activities as well as for plans aiming at developing geosites.

\section{Stratigraphy and Significance of the Kálvária Hill Mesozoic Succession}

The Mesozoic of Tata is described in the comprehensive and abundantly illustrated monograph by Fülöp (1976). Due to the favourable outcrop conditions several formations were studied in detail for the first time on the Kálvária Hill by Fülöp (1976), and type localities of three of them have been designated there. At the Kálvária Hill, an approx. 50-m-thick Upper Triassic to Lower Cretaceous (Aptian) succession is exposed (Fig. 3).

The oldest rock exposed is Dachstein Limestone once exploited extensively in the "Whitestone Quarry" located outside the Geological Garden (Fig. 4).

Macro- and microfossils indicate a Rhaetian, i.e. Late Triassic age of it. A wide variety of sedimentary environments ranging from areas exposed sub-aerially at times to lagoons of some metre depth are represented in the succession. Beds deposited in lagoons are the most frequent and contain abundant megalodontid
Fig. 3 Stratigraphic column of the Mesozoic cropping out at the Kálvária Hill of Tata. (Oxford.Kimm. Oxfordian-

Kimmeridgian, Se. Series, L. Lower, M. Middle, U. Upper, Sy. Systems, Cret. Cretaceous) (after Haas 2007, modified)

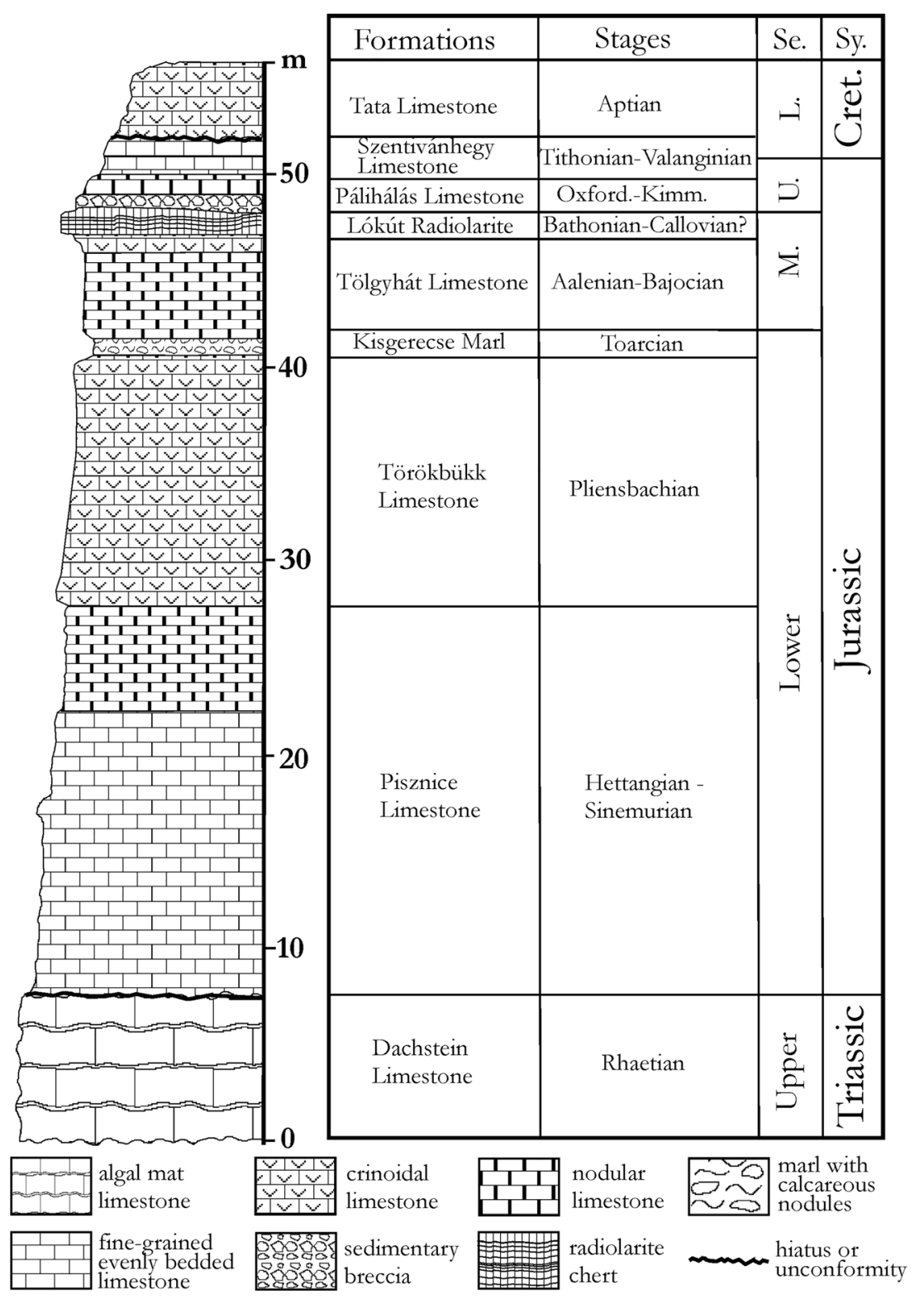


Fig. 4 The "Whitestone Quarry" exposing Dachstein Limestone overlain by Lower Jurassic limestone (Pisznice Limestone) and Rhaetomegalodon incisus, an age-diagnostic (Rhaetian) bivalve from the former one. The specimen is approx. $8 \mathrm{~cm}$ high. The dashed line marks the Triassic-Jurassic boundary

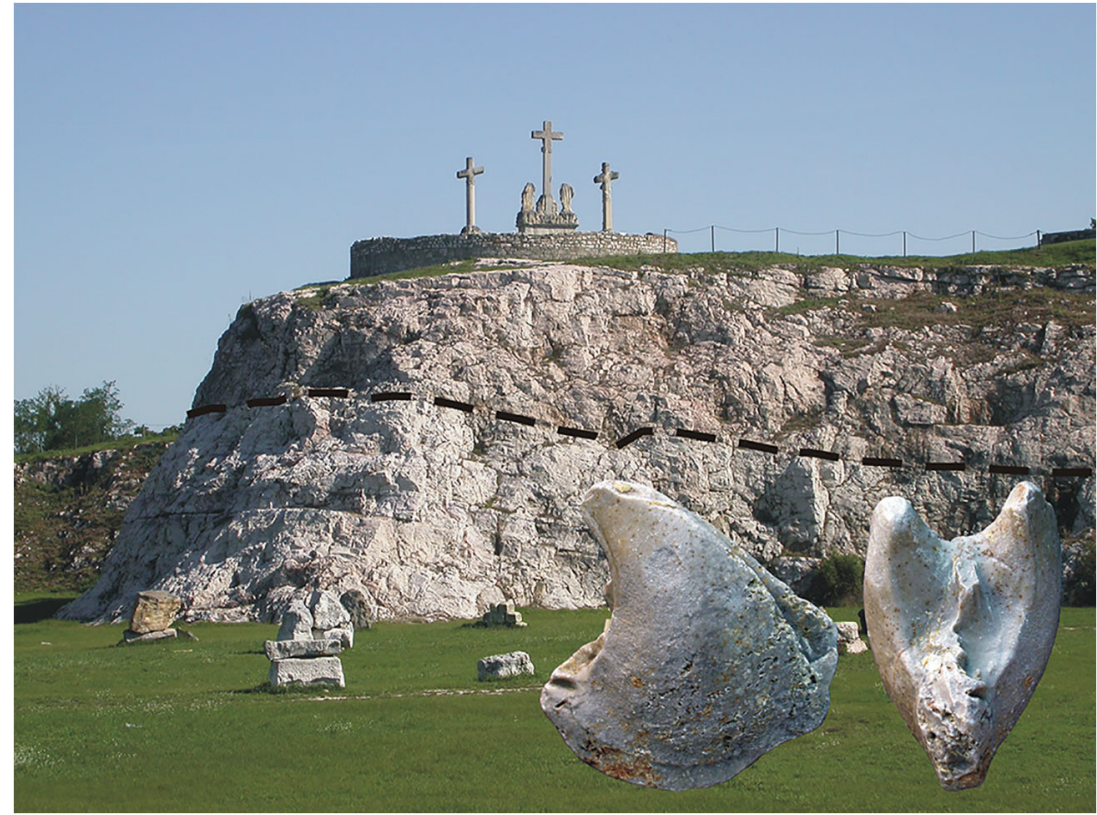

bivalves (Fig. 4), studied in detail by Végh-Neubrandt (1982).

The boundary between the Triassic and Jurassic is a flat erosion surface truncating megalodontid bivalves at some places. Dachstein Limestone is overlain by pink then red fine-grained Jurassic limestone beds assigned to the Pisznice Limestone Formation of Hettangian and Sinemurian age. The Middle Hettangian age of the onset of Jurassic sedimentation was refined recently by Pálfy et al. (2007). The Pliensbachian Stage is represented by an intensively bioturbated encrinite, i.e. a crinoidal limestone known as Törökbükk Limestone Formation. The forementioned formations, usually referred to as "Gerecse red marble" in the older literature, are magnificently exposed in the wide quarry wall, i.e. the former "Redstone Quarry", of the Geological Garden (Fig. 5). The "red marble" is exploited in the Gerecse Mountains since centuries, leaving a plenty of abandoned quarries hidden in the forest. Although named after a quarry situated in the northern Gerecse Mountains, Törökbükk Limestone has been introduced by Fülöp (1976) on the basis of the "Redstone Quarry" section.

The "red marble" is more than $30 \mathrm{~m}$ thick, while cumulative thickness of the younger Jurassic strata does not reach $15 \mathrm{~m}$. The Törökbükk Limestone Formation is followed by a less than 1-m-thick clayey red succession known as Kisgerecse Marl. This latter unit of Toarcian age is rather
Fig. 5 The $100 \mathrm{~m}$ wide and around $15 \mathrm{~m}$ high quarry wall exposing an undisturbed Upper Triassic-Lower Jurassic limestone succession is far the most salient element of the view of the lower yard of the Geological Garden. A segment of the wall appearing as an oblique darker band in the photograph has not been cleaned in order to display the state of the wall before the cleaning action of 2015 as well as to study the effects of weathering and the growth of vegetation

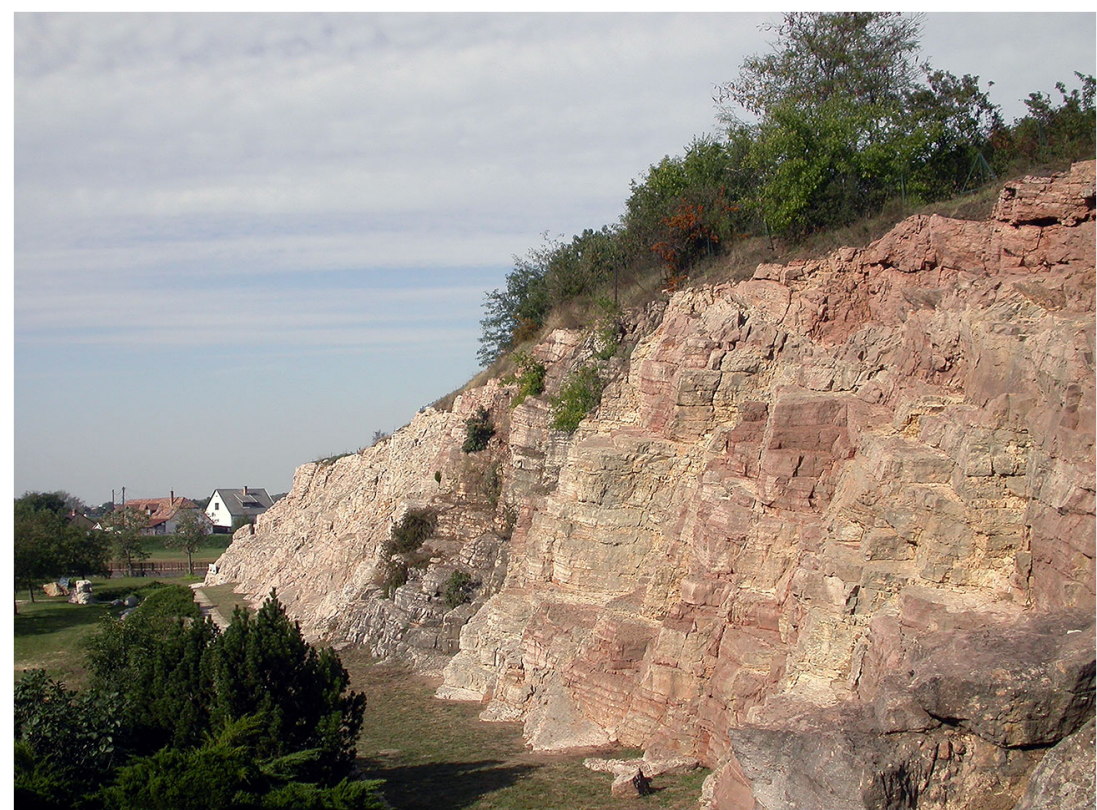


poorly exposed on the surface due to its friable nature. Near the eastern end of the ENE-WSW striking large quarry wall, a normal fault running approximately parallel with it dissects the largely undisturbed Upper Triassic-Lower Jurassic (Pliensbachian) succession. Middle and Upper Jurassic as well as Lower Cretaceous beds can be studied in excellent exposures of more than $2500 \mathrm{~m}^{2}$ extent some meters higher, in the upper terrace (Figs. 6 and 7).

The older part of the Middle Jurassic series, attributed to the Tölgyhát Limestone Formation, is proved to be considerably diverse in facies: red, marly limestone rich in $\mathrm{Fe}-\mathrm{Mn}$ oxide nodules, crinoidal layers as well as beds containing small-sized bivalve shells in rock-forming quantity occur. In the second half of the Middle Jurassic, the nature of sedimentation changed fundamentally: accumulation of calcium carbonate was largely replaced by silica-rich deposits now forming the Lókút Radiolarite Formation. The material of the minute siliceous tests of radiolarians was usually dissolved during diagenesis and has been precipitated as chert layers and nodules later exploited by the Late Neolithic men.

The basal member of the Upper Jurassic is a peculiar sedimentary breccia bed of some tens of centimetres in thickness, forming a conspicuous marker horizon covering the radiolarite much less resistant to surface weathering (Fig. 8).

The origin of the enigmatic "Oxfordian Breccia" (also known as "Oxfordian Bed"), a widespread member in the Gerecse Jurassic characterized in detail by Fodor and Főzy (2013), is still to be found. According to Fodor and Fözy (2013), it represents most probably a single depositional event, e.g. gravity-driven re-deposition of lime mud. On the other hand, $\delta^{13} \mathrm{C}$ values usually show a systematic shift through the bed, indicating deposition over an extended

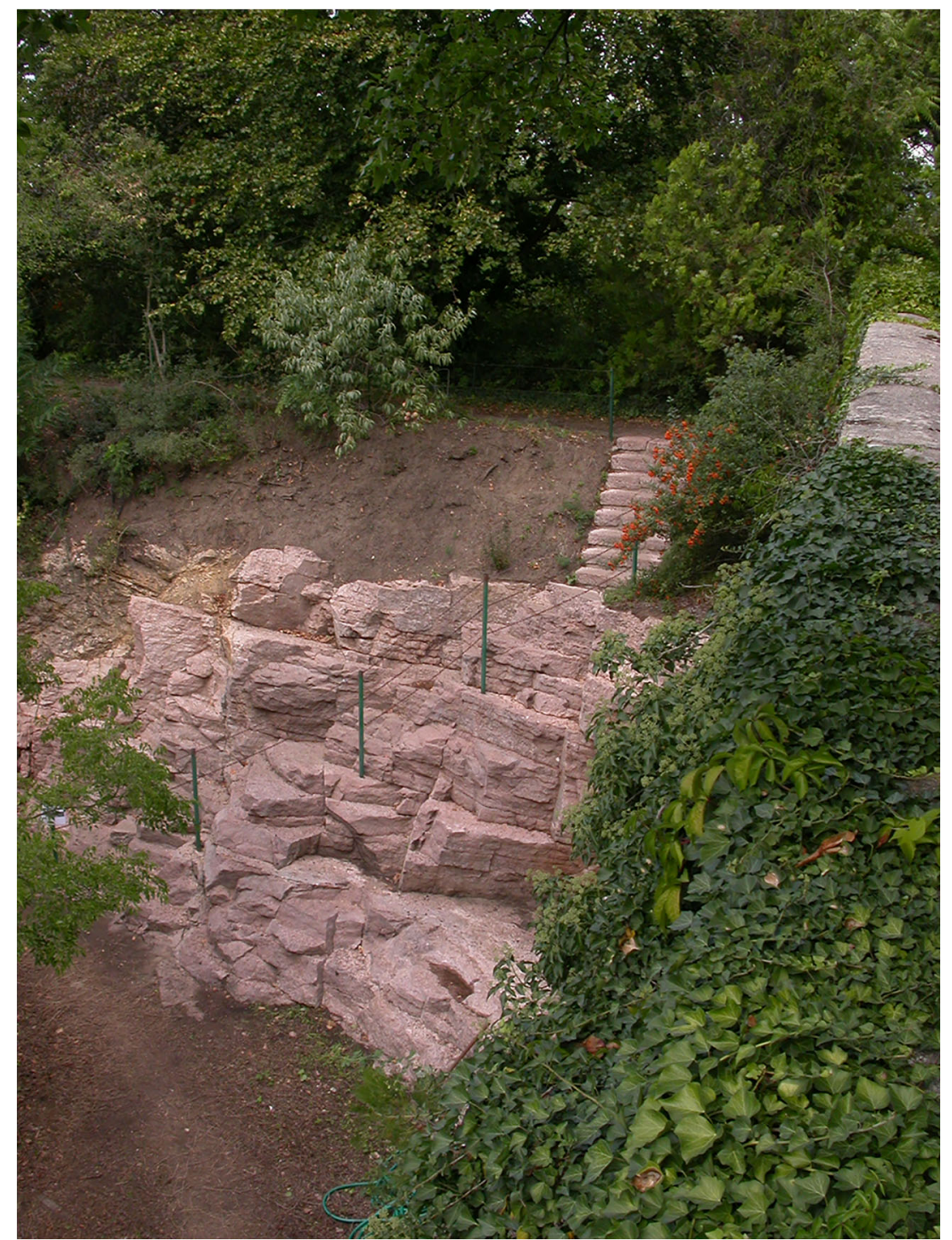

Fig. 6 A stairway formed by and made of Lower Jurassic crinoidal limestone connects the lower and upper yards of the Geological Garden. The photo has been taken from the wall of the neighbouring Jewish Cemetery 
Fig. 7 The upper cleaned rock surface, exposing an eastward dipping Jurassic (Pliensbachian to Oxfordian) succession, with the exhibition hall built above the prehistoric chert pits in the background. Flags were placed to indicate the faults and other phenomena interesting for the wider public on the public outreach of the closing ceremony of the cleaning project in August of 2015

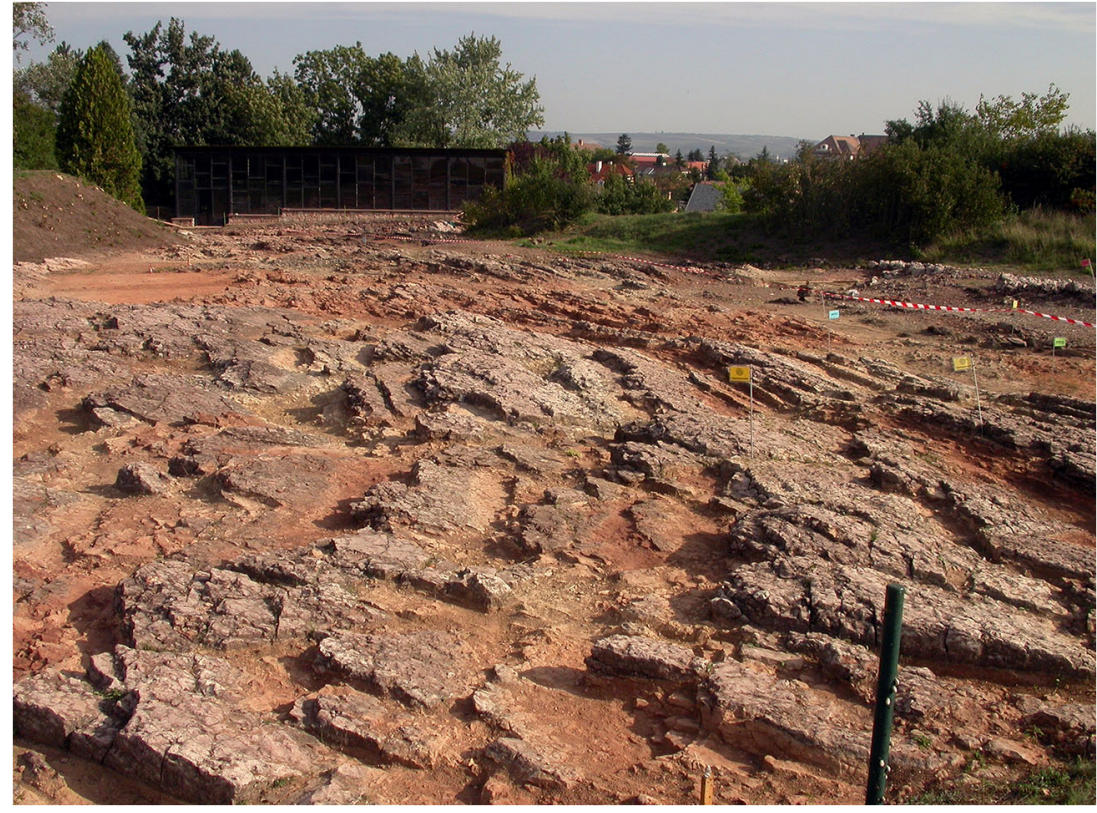

period (Price 2013). Higher parts of the Upper Jurassic as well as the lowermost Cretaceous are developed in a thin succession of pelagic limestone. Bedding planes of the condensed Pálihálás Limestone of Kimmeridgian age appear as "ammonite pavements" and are highlights of the Geological Garden. The Jurassic/Cretaceous boundary can be drawn within the Calpionellid-rich Szentivánhegy Limestone. The latter represents the Tithonian, Berriasian and partly Valanginian stages and has been named after the medieval settlement (Szentivánhegy) once located on the Kálvária Hill, that time called Szentiván Hill. Jurassic/Cretaceous boundary beds were studied in detail recently by Szinger et al. (2007) and
Tithonian bivalves were described by Szente (2013). Unfortunately, the rich and well-preserved Upper Jurassic ammonite assemblage collected bed-by-bed and studied by Gyula Vigh has remained documented only in form of faunal lists published in Fülöp (1976) until now.

The present-day area of the Transdanubian Range was deformed during the Berriasian to Barremian Ages of the Early Cretaceous, due to the first Eoalpine compressional phase. As a result, a submarine high located in its central part, including the environs of Tata, was formed (Tari 1994; Budai et al. 2018). There, the more or less continuous marine sedimentation that began in the Olenekian Age of the Early Triassic and
Fig. 8 Radiolarite chert layers overlain by the "Oxfordian Breccia" (marked with "OB”), a characteristic member of the Kálvária Hill Jurassic

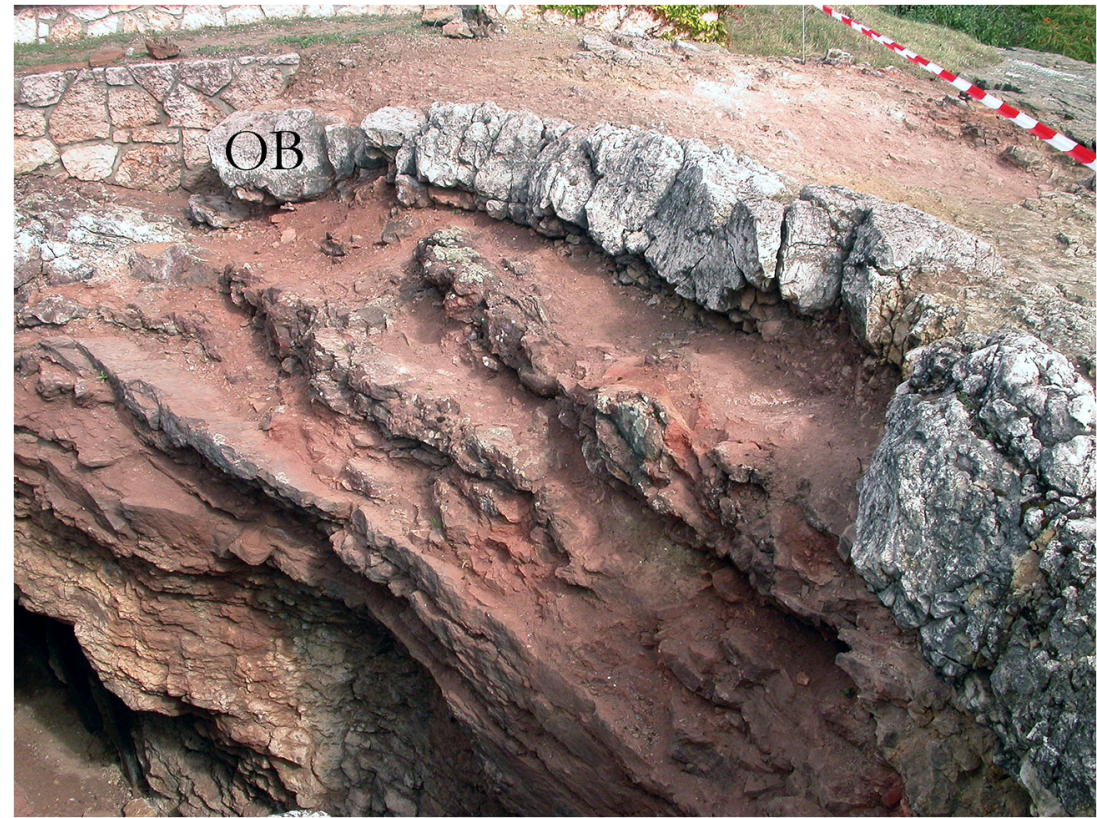


Fig. 9 Angular unconformity between Upper Jurassiclowermost Cretaceous limestone beds and Tata Limestone in the "Bluestone Quarry". The man and the wheelbarrow are standing on the uneven bedding surface of the Szentivánhegy Limestone. Gently dipping beds of Tata Limestone are exposed behind him.

Unconformity surface is indicated by arrow

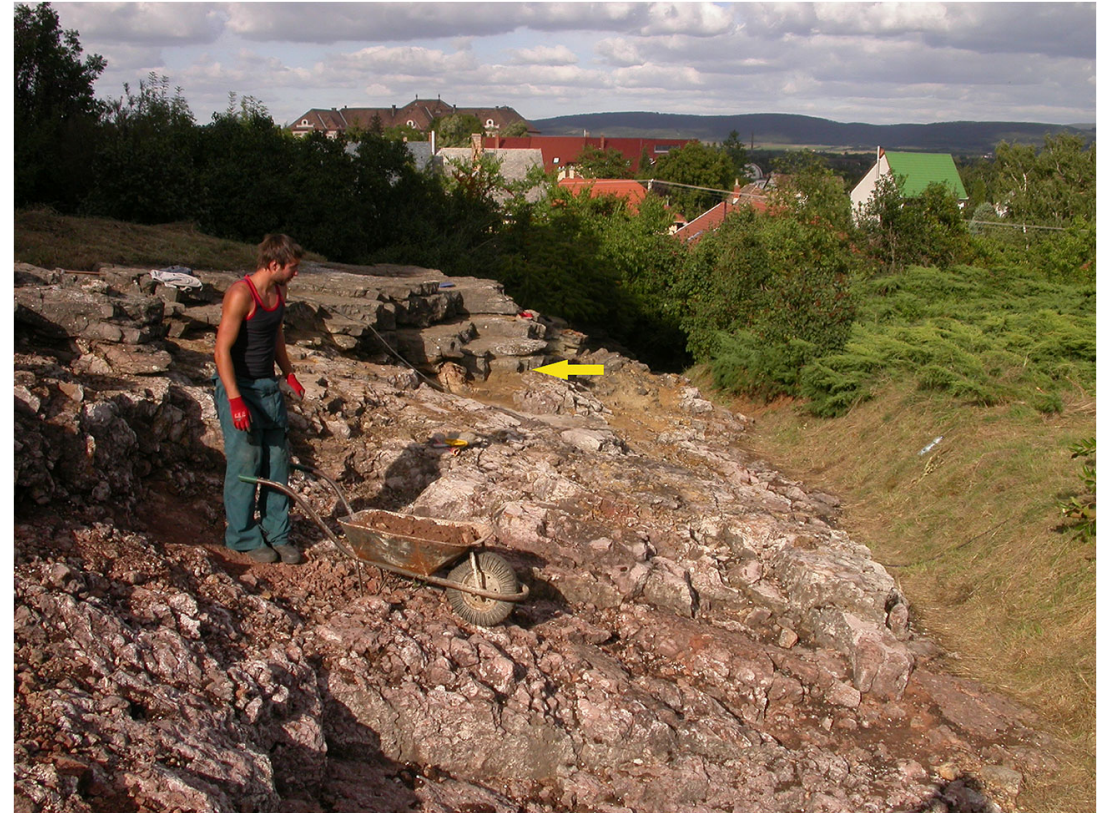

lasted for more than 110 million years until the Valanginian Age of the Cretaceous was interrupted. Structural and sedimentary evolutions of the Gerecse Mountains and its environs including Tata were studied in detail recently by Fodor (2013). On the Kálvária Hill, approximately 20 million years, representing the Late Valanginian, Hauterivian, Barremian and Early Aptian Ages, is not recorded in rocks. The sedimentation, renewed around 115 million years ago in the Clansayesian Subage of the Late Aptian, led to the deposition of the Tata Limestone, a formation widely distributed in the Transdanubian Range between Tata and the town of Sümeg in the west. It overlies the eroded surface of tilted Upper Jurassic limestone beds (Fig. 9). The surface is encrusted by a spectacular, 1-2-cm-thick brownish-yellow layer of presumably microbial origin.

Tata Limestone, once exploited in the "Bluestone Quarry" at the Kálvária Hill, is the youngest known example of the vanished lithofacies "regional encrinite" sensu Ausich (1997), i.e. a crinoidal formation of several tens of meters thickness and several tens of kilometres areal extent, which has no counterpart in modern seas. Type sections of the Szentivánhegy and Tata Limestones have been designated in the "Bluestone Quarry" by Fülöp (1976).

Tata Limestone is an appropriate building stone but extremely poor in identifiable fossils. In small depressions of the uneven surface of the Upper Jurassic limestone, however, a large amount of fossils, especially ammonites, brachiopods and gastropods, have been found (Fig. 10). The ammonite assemblage was published by Szives (2007). Several new ammonite species, e.g. Constrictoceras foezyi-named after the acknowledged palaeontologist István Főzy-and C. steineri-named after Tibor Steiner, the leading collector

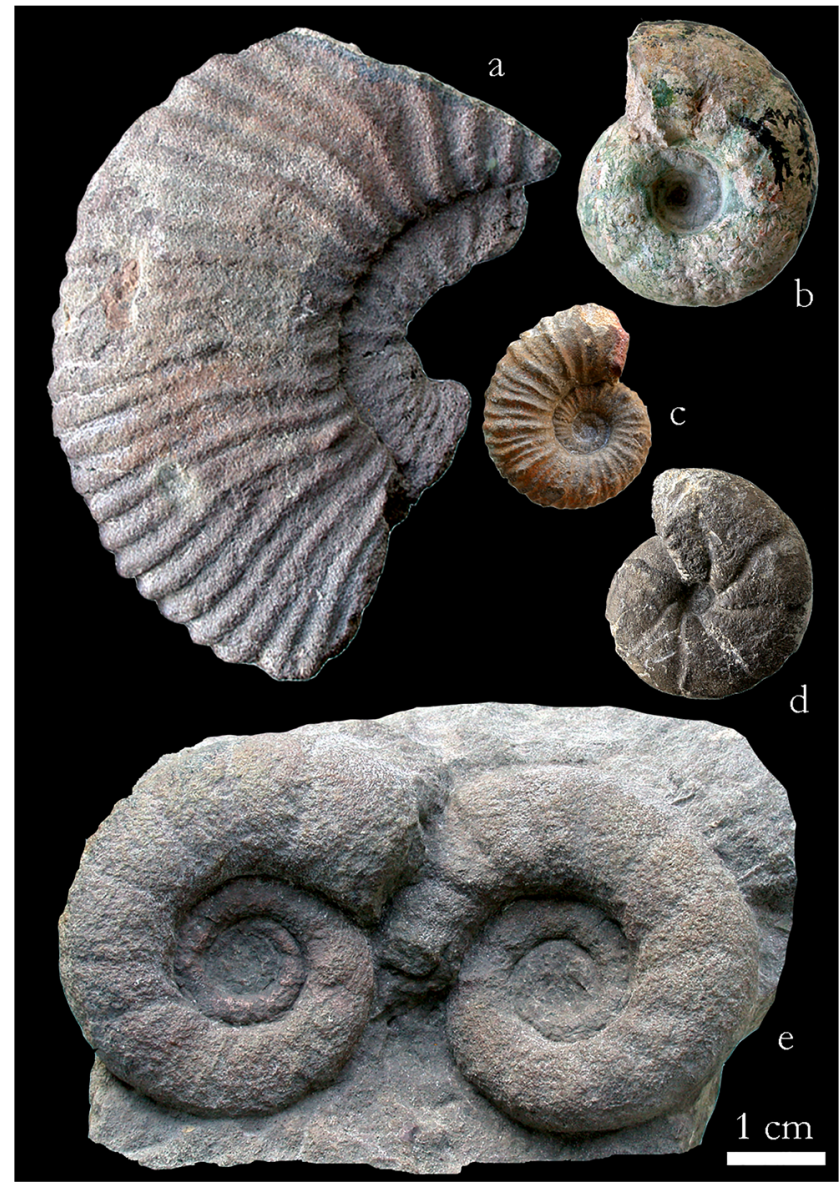

Fig. 10 Aptian (Lower Cretaceous) ammonites from the basal layers of the Tata Limestone. (a) Parahoplites melchioris. (b) Valdedorsella getulina. (c) Cheloniceras cornuelianum. (d) Holcophylloceras guettardi. (e) Tetragonites duvalianus 
of the "Fülöp Aptian Collection", now retired keeper of the Geological Garden - have recently been described by Szives (2008) from the area. Such limestone bodies full of fossils were encountered at the base of the crinoidal limestone succession proper only at three places in the whole Transdanubian Range. Cretaceous rocks younger than Tata Limestone, although encountered in trenches, wells and boreholes to the north-east and south-east of the Geological Garden, are known only from the sub-surface.

\section{The Cleaning Action of 2015: Observations and Results in Geosite Conservation}

In 2014, Eötvös University received a grant of $175,300 €$ from the European Union in the frame of the programme "Environment and Energy Operational Programme" (Project "Reconstruction of Key Geological Sections at the Tata Nature Conservation Area"). Due to the nature of the administration process related to the project, the work began as late as July of 2015. Thus, largely 2 months was available for the realization of the project instead of the one and a half year originally planned.

The support provided a good opportunity to stop "forestation" and renewal the garden. The work was done by a professional company, as well as by the staff of the Geological Garden. Plants, soil and loose rock pieces were removed from quarry walls and rock surfaces using hand tools. Flamethrower and environmentally sound defoliant chemicals were also used in the elimination of undesirable vegetation. Steep walls were accessed using ropes and abseiling equipments. The final cleaning of the rock surfaces was carried out by water-blasting (Fig. 11).

Near $60 \mathrm{~m}^{3}$ of rock debris and soil were found to be necessary to remove. Thus, a little bit more than 1-cm-thick layer had to be removed as an average. The actual amount, however, significantly depended on the dip of rocky surface and, principally, on lithology. Toarcian marl and BathonianCallovian radiolarite beds as well as Middle Jurassic limestones were found especially deeply weathered. The subsidy contract has excluded the opportunity to take over any material from the area of the Geological Garden. A part of the debris, removed formation-by-formation, has been stored in waggons and is available to visitors as samples of local rocks. Radiolarite chert, i.e. the raw material of prehistoric tools, proved to be a popular souvenir since then, especially among children. Fossils gathered during the cleaning action are housed in the collection of the Geological Garden. The remaining bulk of the material has been used to construct a new ramp making accessible a spectacular exposure of Lower Jurassic crinoidal limestone (Fig. 12).

In addition to cleaning, representative rock surfaces easily accessible to visitors have been polished and informative boards have been placed. Other results of the renewal include the discovery of a chert mine located outside of the archaeological exhibition building.

Constructional operations were found to be necessary in 2015 at two sites. Near its eastern end, the wall of the "Redstone Quarry" dissects a normal fault running largely parallel with it. The resulted quarry face exposing stratigraphically younger formations was judged by an expert as unstable and dangerous due to the weakening of rock bodies caused by the fault as well as to the friable
Fig. 11 Water-blasting proved to be very effective in cleaning lichen-covered limestone surfaces such as the ammonite-rich Upper Jurassic bedding-plane exposed in the "Bluestone Quarry"

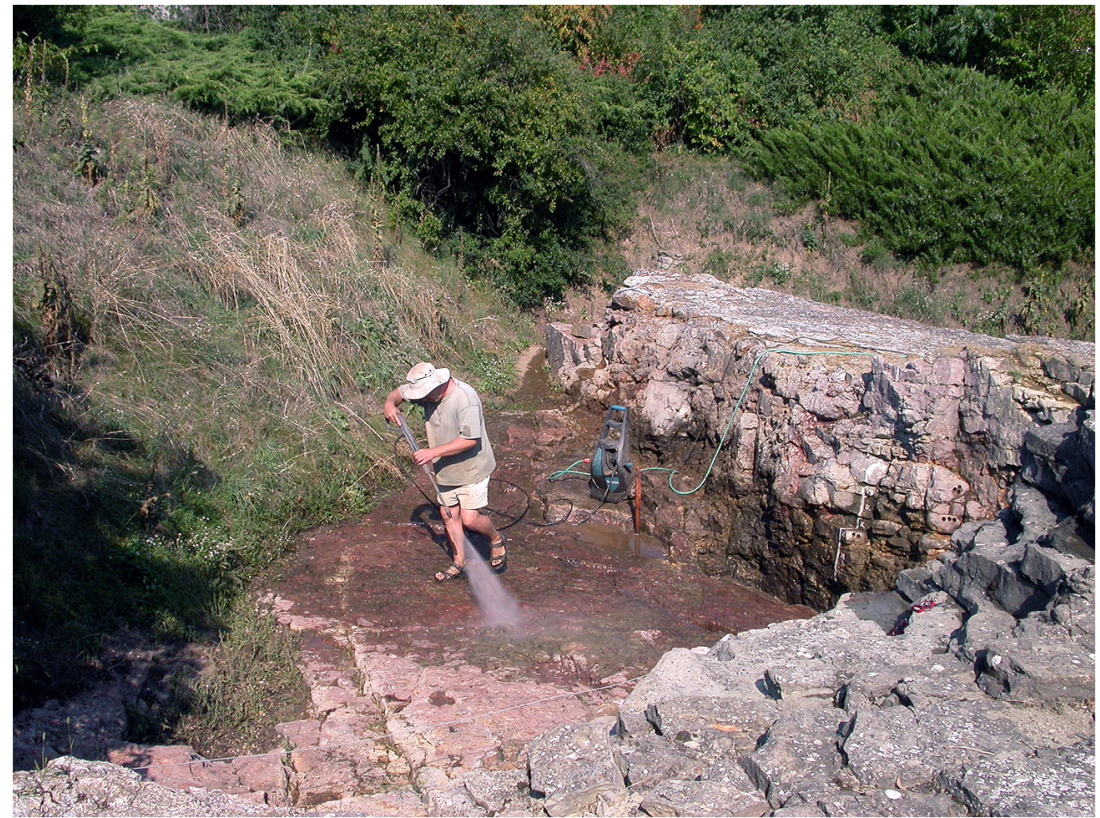




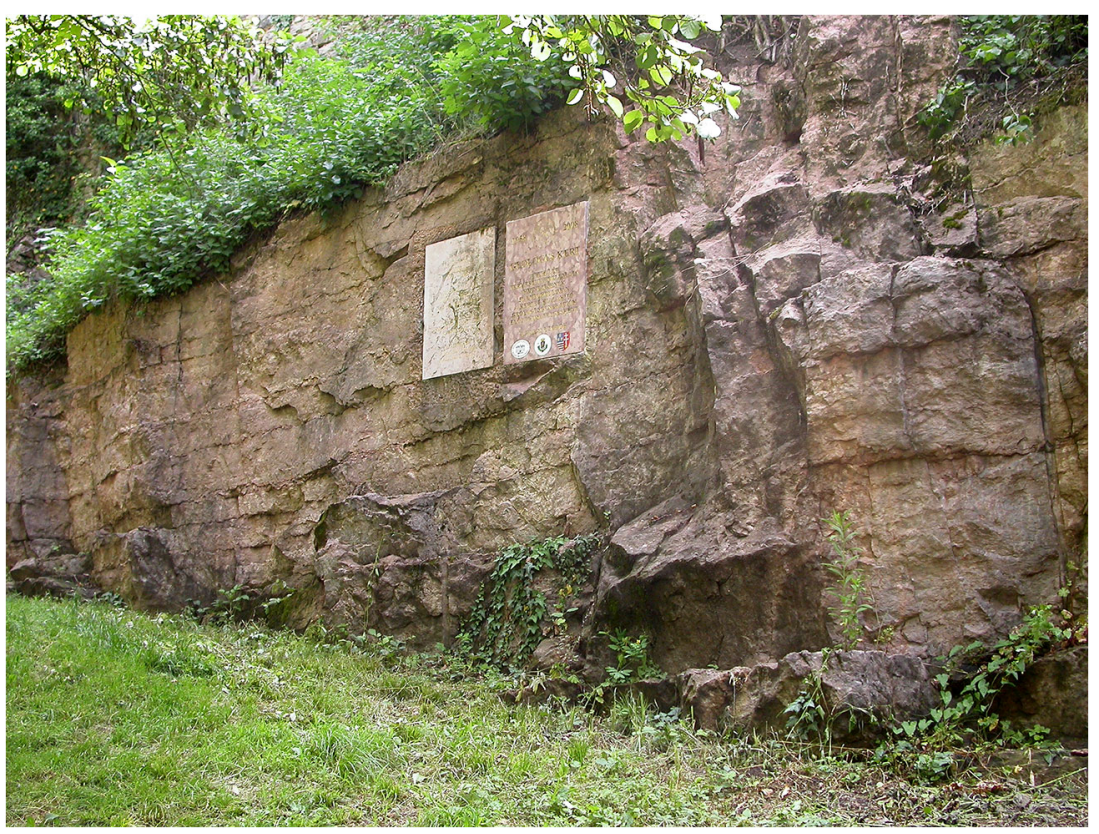

Fig. 12 The ramp constructed of rock debris and soil removed during the cleaning action made this small quarry opened in Lower Jurassic crinoidal limestone easily accessible. The left memorial plaque was unveiled in 1969 on the centenary of the Hungarian Geological Institute. The right one has been presented by the Eötvös University in 2008 on the occasion of the 50th jubilee of the Geological Garden as a nature conservation area. Limestone blocks exploited here were used as plinth of the Joseph Stalin monument, completed in Budapest in 1951 and torn down in 1956 nature of the Kisgerecse Marl. In order to prevent the fall of large blocks, two supporting walls have been built (Fig. 13). Another place where building operation, i.e. construction of a supporting pillar proved to be necessary, was a part of the wall of the neighbouring Jewish Cemetery built in close proximity to the staircase connecting the lower and upper yards of the Geological Garden. There, a test trenching revealed that the wall has been masoned directly on Upper Miocene sand with no foundation. Both the supporting walls and the pillar have been made of local Lower Jurassic limestone.

The project provided opportunity to renew the drainage system of the archaeological exhibition building as well. Previously, the rainwater accumulated on a large part of the upper cleaned surface was thought to be piped through a tube made of asbestos, laid beneath the ground of the exhibition building. In 2015, the old pipe, presumably cracked, was found to be near completely closed up by an 8 -m-long tissue of fine roots. The new pipe bypasses the building and cleaning sockets have also been installed.

\section{Results of the Geodetic Survey}

Within the 2015 cleaning project, geodetic survey of the whole Geological Garden as well as 3D scan of selected quarry walls and rocky surfaces were carried out. At first, a dense and precise network of reference points was established. The network was measured by total station and was adjusted as a free network using GeoEasy software (Siki 2018). For horizontal and vertical localization, most of the reference points were determined by RealTime Kinematic Global Navigation Satellite System (RTK GNSS) technique using corrections of the Hungarian GNSS-infrastructure (https://www.gnssnet.hu). As control, independent reference points were also used. Altogether, the network is about centimetre accurate in horizontal and millimetre accurate in vertical sense. At second, the relevant detailed points were measured using traditional tacheometry and total stations. At the end, a digital map with 1:500 scale was drawn in a QGIS project, with layers:

- Land registry maps, as plots, buildings, parcel numbers

- Orthophoto made in 2013, available at http://www.fentrol. hu/en/

- Digital terrain model and contour lines

- Fences, buildings, inner roads, most important trees

- Important geological objects, such as Triassic/Jurassic boundary

Surprisingly, the surveying resulted in recognition of considerable difference between the extent of the area really occupied by the Geological Garden ( $3.5 \mathrm{ha}$ ) and that indicated by the land registry (2.8 ha). The difference largely lies in the fact that some 0.7 ha, owned by the town, was fenced by the Hungarian 
Geological Institute in the 1970s. After recognizing this problem, negotiations were initiated between the stakeholders and since then, the municipality of Tata voted to assign the right of management of the area to Eötvös University.

Results of the geodetic survey and 3D scan are the basis of a digital 3D geological model, whose development is in progress. Geological results of the surveying include ascertainment of the structure of the rock mass forming the lower yard of the Geological Garden as well. Triassic/Jurassic boundary can be well identified both in the "Whitestone Quarry" and in the quarry situated in the lower yard. The characteristic points of this boundary were measured in three dimensions, and a regression plane was determined on the measured points using GeoEasy software (Siki 2018). The residuals of this regression plane are at decimetre level, and the parameters of the regression plane fits the one determined by Fülöp
(1976), indicating that there is no fault between the quarries mentioned.

\section{Present-Day Activities and Planning for the Future}

The last 2 years saw a welcome increase in the number of the staff that makes maintenance much more efficient as compared to the preceding decades. Since 2016, one of the staff members has been working in the frame of the programme "Workfare work in museums", coordinated by the Hungarian National Museum, and another one is employed by the local community of Tata. Additional to that, since that year, the botanical values of the Geological Garden have been maintained by a gardener expert employed by the University. As a consequence of the work carried out by the staff, long
Fig. 13 Due to a normal fault, Lower Jurassic crinoidal limestone beds exposed in the lower half of the wall are in juxtaposition with younger Jurassic formations. The stone masonry partly visible to the right of the wooden scaffolding was built to support the block of thinly bedded Middle Jurassic limestone undercut by the erosion of Toarcian marl (poorly exposed). The former small-shot producing tower, now used as lookout tower, is visible in the background

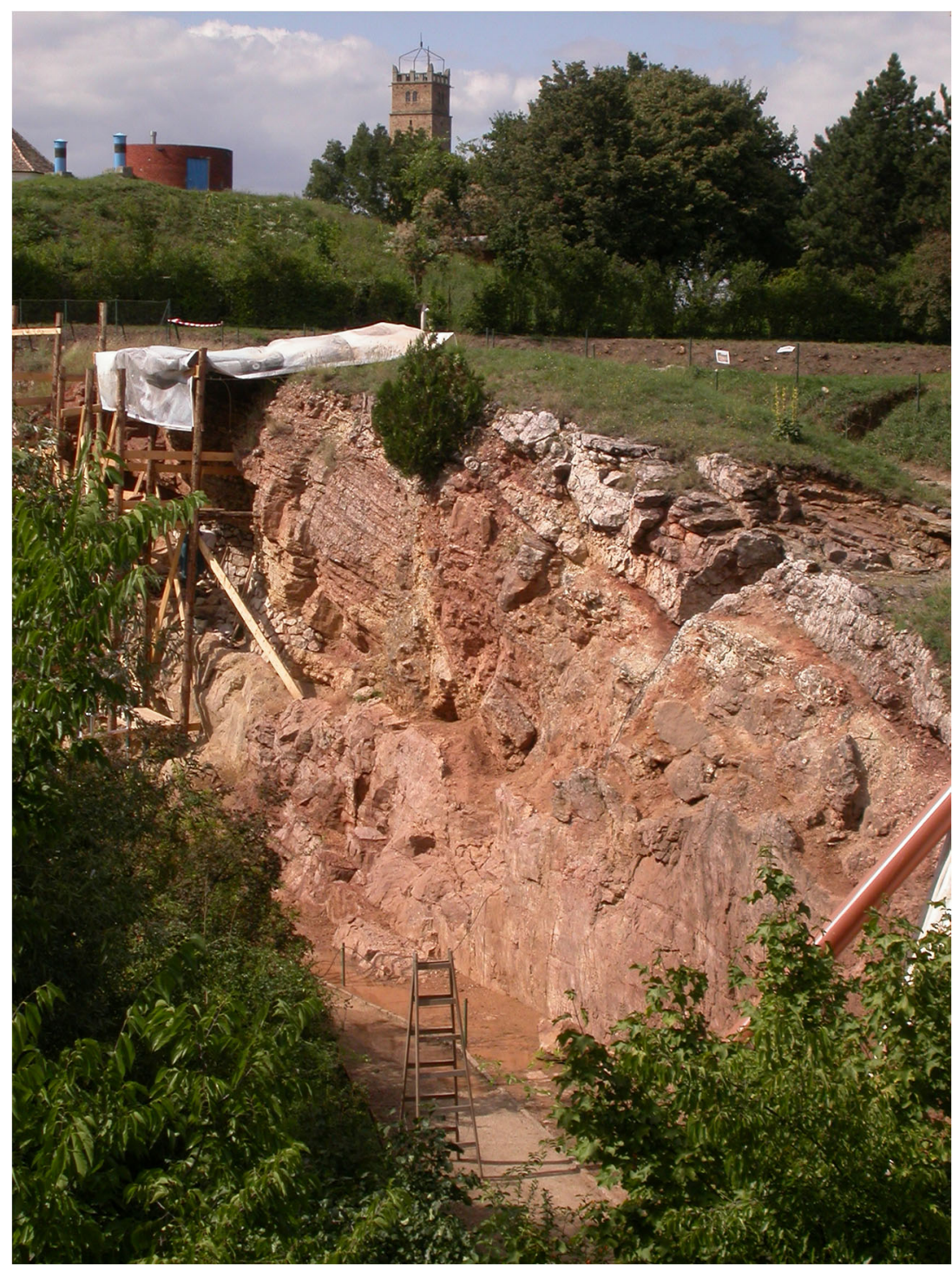


unremembered stairways and paths have been re-conquered from the vegetation since 2016. Two more years seem necessary, however, to clean up the garden entirely. Recently, however, a new gardening problem has arisen. When forming the garden at the lower yard of the Geological Garden in the early 1980 s, different trees have been planted in $1 \times 1-\mathrm{m}$ pits sunk into Dachstein Limestone using explosives. Some trees have already outgrown their pits and withered. Finding the fittest species and planting them are tasks for the future.

The chert pit discovered in 2015 was excavated in 2017 and 2018, in co-operation with the Hungarian National Museum. The majority of the work was done by the enthusiastic volunteers during the camps organized in the hottest summer weeks by the distinguished archaeologist Katalin Biró-T. The main results of the recent three-year excavation series are three antler tools, reconstructed from chips and deposited in the Neolithic Collection of the Hungarian National Museum (Bir-T et al. 2018).

Although some stratigraphic intervals of the Mesozoic succession of the Kálvária Hill have been studied in very detail in the past, some important questions are still unanswered. The cleaning action served as a good opportunity to collect rock samples from the Middle Jurassic succession whose stratigraphy is poorly known. Identification of the Tithonian bed from which the calcareous alga Clypeina jurassica was mentioned by Szabó (1961) is also a challenge, this tantalizing record being the first-found evidence of photic zone in the Upper Jurassic of the Transdanubian Range.

Maintenance of the newly excavated chert pit as well as the state of the sub-horizontal cleaned rock surfaces raised the question whether they can be conserved for a long time in their present state or not. 3D scanning and filling them seem to be an alternative. In that case, visitors could see the rocks lying beneath their feet using VR glasses.

In the last years, efforts were made by the management of the Geological Garden to obtain financial assistance for building a visitor centre involving a lecture room necessary for developing new geoeducational programmes.

\section{Discussion and Conclusions}

As in most countries, geology does not appear as an independent discipline in primary and secondary school curricula in Hungary and is taught in the frame of "Earth and environment", a subject whose proportion has been reduced in the last decades if the total number of lessons is considered. It is therefore of primary importance to utilize the educational opportunity provided by the elements of the geological heritage. Geosites, if appropriately selected and maintained, offer especially good opportunities to teach geology to students (Meléndez et al. 2007). Abandoned quarries often serve as valuable resources for education (e.g. Macadam and Shail
2002; Stefano and Paolo 2017; Prosser 2019). The Geological Garden well fulfils the criteria of pedagogical geosite and widely used as locale of open-air geological lectures. In the last 4 years, altogether more than 1000 students, corresponding to about $15 \%$ of the visitors, learned geology over there.

The Geological Garden of Tata in its renewed form provides visitors a unique opportunity in Hungary to study a spectacular succession of Mesozoic marine sedimentary rocks, as well as prehistoric chert mines, in easily accessible abandoned quarries and other exposures concentrated in a well-groomed garden environment. Keeping rocky surfaces clean, however, would require regular removal of loose rocks, soil and plants. More than 20-year-long pause in this kind of maintenance had resulted in considerable fragmentation of rocky surfaces and lead to the aesthetic deterioration of the Geological Garden. Observations made during the large-scale cleaning action of 2015 clearly indicate that suitably frequent removal of vegetation would be fundamentally important. Obtaining financial assistance to build a visitor centre with a lecture room is another challenging task for the future.

Acknowledgments Thanks to Zoltán Varga, keeper of the Geological Garden, for his help and hospitality. Thanks to Dóri Farkas, as well, for taking part in the geodetic survey and preparing an excellent diploma thesis. Constructive comments by Ewa Głowniak and Kevin Page editors as well as by three anonymous referees are also gratefully acknowledged herein. Cleaning and surveying work was supported by KEOP-3.1.2/2F/ 09-11 project.

Funding Information Open access funding provided by Eötvös Loránd University (ELTE).

Open Access This article is distributed under the terms of the Creative Commons Attribution 4.0 International License (http:// creativecommons.org/licenses/by/4.0/), which permits unrestricted use, distribution, and reproduction in any medium, provided you give appropriate credit to the original author(s) and the source, provide a link to the Creative Commons license, and indicate if changes were made.

\section{References}

Ausich WI (1997) Regional encrinites: a vanished lithofacies. In: Brett CE, Baird GC (eds) Paleontological events, stratigraphic, ecological and evolutionary implications. Columbia University Press, New York, pp 509-520

Beranová L, Balej M, Raška P (2017) Assessing the geotourism potential of abandoned quarries with multitemporal data (České Středohoří Mts., Czechia). GeoScape 11(2):93-111

Biró-T K, Harman-Tóth E, Dúzs K (2018) New research at TataKálváriadomb, Hungary. In: Werra HD, Woźny M (eds) Between history and archaeology - papers in honour of Jacek Lech. Archaeopress Publishing Ltd, Oxford, pp 49-57

Brilha J (2016) Inventory and quantitative assessment of geosites and geodiversity sites: a review. Geoheritage 8(2):119-134 
Brilha J (2018) Geoheritage: inventories and evaluation. In: Reynard E, Brilha J (eds) Geoheritage: assessment, protection and management. Elsevier, Amsterdam, pp 69-85

Budai T, Fodor L, Csillag G, Zs K, Sztanó O, Selmeczi I, Lantos Z, Ruszkiczay-Rüdiger ZS (2018) Geological history of the Gerecse. In: Budai T (ed) Geology of the Gerecse Mountains. Mining and Geological Survey of Hungary, Budapest, pp 387-398

Fodor L (2013) Deformation of the late Middle to Late Jurassic sediments in the Gerecse Mountains. In: Fözy I (ed) Late Jurassic-Early Cretaceous fauna, biostratigraphy, facies and deformation history of the carbonate formations in the Gerecse and Pilis Mountains (Transdanubian Range, Hungary). GeoLitera Publishing House, Institute of Geosciences, University of Szeged, pp 101-116

Fodor L, Fözy I (2013) Late Middle Jurassic to earliest Cretaceous evolution of basin geometry in the Gerecse Mountains. In: Fözy I (ed) Late Jurassic-Early Cretaceous fauna, biostratigraphy, facies and deformation history of the carbonate formations in the Gerecse and Pilis Mountains (Transdanubian Range, Hungary). GeoLitera Publishing House, Institute of Geosciences, University of Szeged, pp 117-135

Fülöp J (1954) Geological study of the Mesozoic horst block of Tata. Földtani Közlöny 84:309-325 (in Hungarian)

Fülöp J (1973) Funde des prähistorisches Silexgrubenbaues am KálváriaHügel von Tata. Acta Archaeologica Academiae Scientiarum Hungaricae 25:4-25

Fülöp J (1976) The Mesozoic basement horst blocks of Tata. Geologica Hungarica Series Geologica 16:2-229

Haas J (2007) Geological Garden in Tata, Transdanubian Range, Hungary. Nova Acta Leopoldina Neue Folge 94:237-251

Horváth G, Lóczy L (2015) Geoheritage, geoconservation, geomorphosites in Hungary. In: Lóczy D (ed) Landscapes and landforms of Hungary. Springer, Cham, pp 281-288

Koch N (1909) Die geologische Verhältnisse des Kalvarienhügels von Tata. Földtani Közlöny 39:285-307

Lóczy L (1906) Geological observations on the Kálvária Hill of Tata. Földtani Közlöny 36:206-207 (in Hungarian)

Macadam J, Shail R (2002) Chapter six: abandoned pits and quarries: a resource for research, education, leisure and tourism. In: Hartgroves S, Macadam J, Owens D (eds) Spalding A. The conservation value of abandoned pits and quarries in Cornwall, Cornwall County Council, pp 71-80

Meléndez G, Fermeli G, Koutsouveli A (2007) Analyzing geology textbooks for secondary school curricula in Greece and Spain: educational use of geological heritage. Bull Geol Soc Greece 40(4):1819 1832

Pálfy J, Dulai A, Szente I (2007) 2.1/a. Kálvária Hill Quarry, western yard. Upper Triassic (Rhaetian) and lower Jurassic (Hettangian), Dachstein limestone and Pisznice limestone formations. In: Pálfy J, Pazonyi P (eds) Palaeontological field-trips in Hungary and Transylvania. Hantken Press, Budapest, pp 41-44 (in Hungarian)
Peters KF (1859) Geologische Studien aus Ungarn II. Die Umgebung von Visegrád, Gran, Totis und Zsámbék. Jahrbuch der kaiserlichköniglichen geologischen Reichsanstalt 10:482-521

Price GD (2013) Stable isotope variation in the Late Jurassic of the Gerecse Mountains, Hungary. In: Főzy I (ed) Late Jurassic-Early Cretaceous fauna, biostratigraphy, facies and deformation history of the carbonate formations in the Gerecse and Pilis Mountains (Transdanubian Range, Hungary). GeoLitera Publishing House, Institute of Geosciences, University of Szeged, pp 95-99

Prosser CD (2019) Communities, quarries and geoheritage - making the connections. Geoheritage. https://doi.org/10.1007/s12371-01900355-4

Siki Z (2018) GeoEasy an open source project for surveying calculations. Geoinformatics FCE CTU 17(2):8-8. https://doi.org/10.14311/gi. 17.2.1

Stefano M, Paolo S (2017) Abandoned quarries and geotourism: an opportunity for the Salento quarry district (Apulia, Southern Italy). Geoheritage 9(4):463-477

Storemyr P (2006) Reflections on conservation and promotion of ancient quarries and quarry landscapes. In: Degryse P (ed) Proceedings to the First QuarryScapes Symposium, 15-17 October 2006. Antalya, Extended abstract collection, pp 31-35

Szabó I (1961) Die Ausbildungen der mesozoischen Scholle von Tata aus der Jurazeit. Ann Inst Geol Public Hung 49:599-605

Szente I (2013) Late Jurassic bivalves from the Gerecse Mountains and its environs (Transdanubian Range, Hungary). In: Főzy I (ed) Late Jurassic-Early Cretaceous fauna, biostratigraphy, facies and deformation history of the carbonate formations in the Gerecse and Pilis Mountains (Transdanubian Range, Hungary). GeoLitera Publishing House, Institute of Geosciences, University of Szeged, pp 361-375

Szinger B, Görög Á, Császár G (2007) Late Jurassic - Early Cretaceous sections from Tata (Pelso Unit, Hungary): sedimentology, marine palaeontology, palaeoenvironment. Geophys Res Abstr 9:08989 2007 SRef-ID: 1607-7962/gra/EGU2007-A-08989

Szives O (2007) Aptian stage. In: Szives O (ed) Aptian-Campanian ammonites of Hungary, vol 57. Geologica Hungarica Series Palaeontologica, pp 31-74

Szives O (2008) Two new species of Constrictoceras nov. gen. (Ammonoidea) from the early cretaceous (Aptian) of Hungary. Geobios 41:297-308

Tari G (1994) Alpine tectonics of the Pannonian Basin. Dissertation, Rice University

Townson R (1797) Travels in Hungary with a short account of Vienna in the year 1793. GG and J Robinson, London

Végh-Neubrandt E (1982) Triassische Megalodontaceae: Entwicklung, Stratigraphie, Paläontologie. Akadémiai Kiadó, Budapest

von Hauer FR (1853) Ueber die Gliederung der Trias-, Lias- und Juragebilde in den nordöstlichen Alpen. Jahrbuch der kaiserlichköniglichen geologischen Reichsanstalt, vol 4, pp 715-783 